\title{
Religion and Socioeconomic Wellbeing-Empirical Study of the Impact of Religion on Socioeconomic Rights in the Pluralistic and Democratic Context of Tamil Nadu, India
}

\author{
Francis-Vincent Anthony ${ }^{1, *(1)}$ and Carl Sterkens ${ }^{2, *}$ (i) \\ 1 Faculty of Theology, Institute of Pastoral Theology, Salesian Pontifical University, Piazza dell'Ateneo \\ Salesiano 1, 00139 Rome, Italy \\ 2 Faculty of Philosophy, Theology \& Religious Studies, Radboud University, Erasmusplein 1, \\ 6525 HT Nijmegen, The Netherlands \\ * $\quad$ Correspondence: vincent@unisal.it (F.-V.A.); C.Sterkens@ftr.ru.nl (C.S.)
}

Received: 13 July 2020; Accepted: 2 September 2020; Published: 5 September 2020

\begin{abstract}
There is no gainsaying that in a globalized world, economic and technological development greatly determine human wellbeing. In the Indian context, the dialectics between socialist and capitalist economy, while giving way to the latter since 1991, has progressively led to the enlargement of the middle class, yet widened the gap between the rich and the poor. Such a situation points to the importance of socioeconomic rights for guaranteeing human flourishing. The question that we pose is whether religions can play a significant role in favoring these human rights, given their own specific vision of human life and of its socioeconomic facets, such as work, wealth, leisure, health, and education. In other words, can personal and contextual religious attitudes and religious socialization contribute to socioeconomic wellbeing? The empirical research undertaken in the pluralistic and democratic context of Tamil Nadu, India, seeks to verify among 1215 Christian, Muslim, and Hindu students, the impact of religion on their attitude towards socioeconomic rights. The emerging results reveal that some aspects of religious attitudes and socialization have a significant impact on students' agreement with socioeconomic rights, particularly in the case of Christians and Muslims. We conclude with a discussion on the salient findings and their implications.
\end{abstract}

Keywords: socioeconomic rights; human wellbeing; education; democracy; Christianity; Islam; Hinduism

\section{Introduction}

By bringing the global economy to an abrupt halt and portending a recession worse than that of the 1930s, the coronavirus (COVID-19) pandemic has thrown into sharp relief the fragility of neoliberal and gig economy and has raised unsettling questions about the impending end of globalization and, more tragically, of emerging markets. Obviously, the socioeconomic future of India depends not only on the political choices made in the recent past, but also on the world economy and the extent of its human resources. It is not our intention to assess the intense ongoing debate on how economy is to be developed, but to explore a factor less taken into account, namely, the sociocultural conditions and, more specifically, how religious traditions with their own vision of human wellbeing determine the mind-set of people about socioeconomic rights. Religions, with their anthropological vision bound to the transcendent, can differ in their approach to human rights. In effect, the three major religions of India, namely, Hinduism, Islam, and Christianity, engage with human rights in diverse ways. We can, then, expect differences between Christians, Muslims, and Hindus in their attitude towards 
socioeconomic rights, not only on the basis of their specific religious beliefs, practices, and socialization, but also on account of their being minority or majority community: Christians (2.3\% in India, $6.1 \%$ in Tamil Nadu), Muslims (14.2\% in India, 5.9\% in Tamil Nadu), and Hindus (79.8\% in India, $87.6 \%$ in Tamil Nadu). ${ }^{1}$

Our study seeks to address the impact of the three religious traditions on young people's attitudes towards socioeconomic human rights in the democratic Indian context. With this scope in mind, we first offer a brief panorama of the contextual development of Indian economy since independence (Section 1), before proceeding to highlight human rights and constitutional perspectives on socioeconomic wellbeing (Section 2). We then take up the religious perspectives, namely, Christian, Islamic, and Hindu visions of socioeconomic wellbeing (Section 3) that complete the theoretical phase of our study. In the empirical phase, we elaborate the conceptual model and define the research questions (Section 4), present the research design (Section 5), the empirical results (Section 6), and discuss the salient findings and their implications (Section 7).

\section{An Overview of the Development of Indian Economy}

Long before the establishment of the East India Company, India had developed flourishing trade links with the East Asian countries and on the western coast reaching up to the Greco-Roman Empire in the first century Common Era (CE) and successively with the Arab world. The kings of Tamilakam (South India) in particular encouraged such maritime interlocking (Thapar 2014, 2019; Gurukkal 2019; Chakravarti 2019; Raychoudhary 1989, pp. 199-213). However, our focus here is on the development of the Indian economy in the post-colonial democratic era, through the successive socialist and capitalist phases, with reforms of P.V. Narasimha Rao's government in 1991 marking a watershed (Das 2007; Basu 2000).

The first government of independent India headed by Jawaharlal Nehru stimulated industrial development more on the basis of state entrepreneurship than private initiatives. In spite of the desire to build a modern and just India in the perspective of socialism, the 'mixed economy' with its Five-Year Plans (since 1951-1956) and reforms in the agricultural and industrial sectors got trapped in the bureaucratic control of the 'License Raj.' Paradoxically, Indian socialism did not change much the lot of the poor; neither did the rather assertive rule of Mrs. Indira Gandhi during the 1970s (Das 2007, pp. x-xii; Maliekal 1977). According to Das (2007, pp. xii-xvii), there are several reasons why India could not take off with a self-generating growth: Adopting an inward-looking rather than an outward-looking export-promoting route that offers access to the prosperity of the post-war era; a massive, inefficient and monopolistic public sector with little autonomy; overregulation of private enterprises, thus diminishing competitiveness and innovation; discouraging foreign capital, thus losing the benefits of technology and world-class competition; compliance with labor organizations compromising productivity; and ignoring the education of the young, particularly of girls. Concerning the latter, the last decade of the 20th century, however, marks a positive turn-in concomitance with the economic reform - in building human capabilities through education. "A comparison of the 1991 census data and the 1997 National Sample Survey data suggests that this is the decade in which literacy has grown faster than in any previous ten years. In 1991 the literacy rate was 52 percent. By 1997 it had reached 62 per cent. The increase in literacy has been particularly sharp for females, whose literacy rate in 1991 was 39 percent and in 1997 had reached the 50 percent mark" (Basu 2000, p. 202).

The liberalization reform set in motion by Narasimha Rao government in 1991 "opened the economy to foreign investment and trade; it dismantled import controls, lowered customs duties, and devalued the currency; it virtually abolished licensing controls on private investment, dropped tax rates, and broke public sector monopolies. As a result, growth picked up to 7.5 percent a year in the mid-nineties, inflation came down from 13 percent to 6 percent by 1993, exchange reserves shot

1 See http://www.censusindia.gov.in/2011census/C-01.html (accessed on 9 May 2020). 
up from $\$ 1$ billion to $\$ 20$ billion" (Das 2007, p. x). The beginnings of the 21st century has seen the convergence of two global trends to India's advantage: The liberal revolution and the information economy. Given that India, unlike many other countries, embraced democracy first and successively capitalism, the latter should evolve in dialogue with conservative forces of caste, religion, and village, Nehruvian and other forms of socialism, and the new forces of global capitalism. In other words, India should see a more stable, peaceful, and negotiated transition into the future, unlike China or Russia (ibid. pp. xvi-xix). For India has been gradually building up a vibrant and resilient democracy that can alter the condition of the poor. By augmenting the intellectual capital and human capabilities through the expansion of primary education and the quality of the higher education system and taking advantage of the opportunities offered by information technology and globalization, there is the likelihood of conquering the pervasive poverty and illiteracy ensuring equity (ibid. pp. 325-44, 356-66).

The economic development through the years in fact has reduced the poverty rate gradually from $97 \%$ in 1977 to $95.5 \%$ (1987), $92.5 \%$ (2004), 90.6\% (2009), and 86.8\% (2011). ${ }^{2}$ Considering the gross domestic product (GDP) with reference to purchasing power parity (PPP), in 2017 India (\$9.474 trillion) ranked third after the USA ( $\$ 19.49$ trillion) and China ( $\$ 25.36$ trillion). The prevision for the current year-before the COVID-19 pandemic — of the relative national wealth inequality, namely, Gini index 2020, was 35.2 in India, seemingly better than Japan (37.9) and the USA (45). ${ }^{3}$ As for Tamil Nadu, according to the World Bank, ${ }^{4}$ since 1994 there has been a steady decline in poverty, with lower levels than most other Indian states. Although after 2005, Tamil Nadu was among India's fastest growing states, the wealth inequality (Gini index) in the state remains higher than in many other states.

With the impact of the pandemic, the world GDP is forecast to fall by $4.6 \%$ in 2020 , while the forecast for India's GDP is a decline by 5\% for the financial year ending in March 2021, due to the stringent lockdown policy lasting longer than originally expected. ${ }^{5}$ Although there are alternative possibilities, as exemplified by the growth of the Chinese economy, according to Das (2007, p. 354f) the Indian economy could weather this situation, as it has done in the past, to the extent it upholds human rights and its deep religious traditions. The universal and inalienable human rights can be attributed to the liberal conception of humanity founded on the power of reason, and may contribute to eradicating poverty and distress. Nonetheless, the search for freedom and social justice, on the one hand, can run into the trap of bureaucracies suppressing innovation as it seemed to be the case in Nehruvian socialism; and on the other, it can run into the trap of an economic globalization that is merely consumption oriented, giving rise to an alienating homogeneous and faceless world. In such a predicament, the powerful hold of religion and spirituality on the Indian psyche can contribute to finding meaning in the conundrums of socioeconomic life. In other words, the socioeconomic wellbeing calls for a certain complementarity between human rights and religious traditions, which we shall expound in the next two sections.

\section{Human Rights Perspectives on Socioeconomic Wellbeing}

The end of the Second World War elicited a fresh grasp of human dignity and a new world order for ensuring the common good. The human rights tradition that sought to address these urgencies reached its climax with the Universal Declaration of Human Rights (UDHR) in Paris on 10 December 1948, with the post-colonial world of independent nations enshrining diverse features of human rights

\footnotetext{
www.macrotrends.net (accessed on 9 May 2020).

Comparing wealth distribution with Gini coefficients between countries is rather tricky. While Gini coefficients may be similar (e.g., Bangladesh and the Netherlands), the quality of life, economic opportunity, and absolute income in these countries can be very different. This is also the case in comparing India with Japan and the USA.

4 http://documents.worldbank.org/curated/en/380971504177733539/Tamil-Nadu-Poverty-growth-and-inequality (accessed on 9 May 2020).

5 https://www.thehindu.com/news/cities/mumbai/biggest-forecast-cut-for-india-india-fy21-gdp-seen-at-5/article31682861. ece?homepage=true (accessed on 27 May 2020).
} 
in their constitutions. This was the case of India, which became independent on 15 August 1947. We shall briefly highlight the core features of socioeconomic human rights and how they have been honored in the Constitution of India.

\subsection{Core Features of Socioeconomic Rights}

The affirmation of Article 3 of the UDHR — "Everyone has the right to life, liberty and security of person"-may be considered the basis of all other rights. The so-called first generation of human rights, referred to as 'blue rights,' comprise civil liberties besides political and judicial rights as highlighted in the International Covenant on Civil and Political Rights (ICCPR 1966). The second generation, referred to as 'red rights,' include economic, social, and cultural rights, and are spelt out in the International Covenant on Economic, Social, and Cultural Rights (ICESCR 1966). As of 2020, the Covenant has 170 parties; four other countries, including the United States, have signed but not ratified the Covenant. India ratified it on 10 April 1979.6

The third generation of collective rights, namely, the 'green rights' deal with ecological issues, responsibilities for the next generation, and the emerging needs of developing countries. They find expression in the documents of international law, such as the Stockholm Declaration of the UN Conference on the Human Environment (1972), and the Rio Declaration on Environment and Development (1992). The focus is on healthy environment, natural resources, cultural heritage, intergenerational equity, and sustainability.

According to the Vienna Declaration and Program of Action at the World Conference on Human Rights (1993), these rights are indivisible, interrelated, and interdependent (Article 5). In other words, the implementation of civil, political, and judicial rights (first generation) requires the implementation of socioeconomic rights (second generation), and vice versa. It should be noted, however, that some Western countries - at any rate in their dealings with developing countries - tend to lay the accent on first generation rights, while developing countries focus more sharply on second generation rights. In the contemporary context of the ecological crisis, the third generation of rights have become equally important. Nonetheless, in the present study we focus on the socioeconomic rights.

The preamble of UDHR affirms the dignity, worth, and equality of human persons and underscores the effort "to promote social progress and better standards of life in larger freedom." This is further specified as right to work (Article 23), rest and leisure (Article 24), adequate standard of living for oneself and for one's family (Article 25), education (Article 26), and cultural life (Article 27).

These themes are further elaborated by the ICESCR in its preamble and the 31 articles, divided into five parts, of which the third one is central to our discourse. Part III (Articles 6-15) draws attention to the socioeconomic rights such as the right to work and the opportunity to choose it freely, endorsing the necessary technical and vocational guidance, training programs, and policies (Article 6). The Covenant demands that equal remuneration and healthy working conditions be ensured in the case of women and men. Besides, they are to be guaranteed a decent living for themselves and for their families. The workers also have the right to rest, leisure, and reasonable limitation of working hours and periodic holidays with pay (Article 7). To safeguard their rights, they are free to join and establish trade unions and confederations at national and international levels. They also have the right to strike, which however has to be exercised in conformity with the laws of their country (Article 8).

In this vein, the Covenant underscores the workers' right to social security, including social insurance (Article 9). Widening the perspective, it upholds family life, including paid parental leave and the protection of children. Children and young persons are to be protected from economic and social exploitation; from work harmful to their morals or health, hampering their normal development. States are to ensure the prohibition of child labor by law (Article 10).

6 https://www.ohchr.org/en/hrbodies/cescr/pages/cescrindex.aspx (accessed on 30 May 2020). 
With the wages they receive, workers should be able to maintain an adequate standard of living for themselves and their families in terms of food, clothing, and housing (Article 11). Social security must ensure the health of workers, acknowledging their right to the highest attainable standard of physical and mental health (Article 12). In the contemporary world, a precondition for employment is education; therefore, there is the need to ensure free primary education, making possible secondary education, and rendering accessible higher education. The process of education should aim at the full development of the human personality, enabling all to participate effectively in the development of social and cultural life. The State is not to interfere with the liberty of individuals and bodies to establish educational institutions, but respect the liberty of parents to choose for their children schools-approved by the State - that provide the religious and moral education in conformity with their own convictions (Articles 13-15).

Individual attitudes towards socioeconomic rights are likely to be dependent on the attribution of poverty. Bullock (1999) and Cozzarelli et al. (2001) classify the varied attributions as to why the poor are poor: Individualistic reasons hold the person (i.e., personality traits) responsible for his or her poverty; structural reasons hold the social structure responsible for poverty; fatalistic reasons hold nobody responsible for poverty, because it is outside the control of individuals and social structures; and religious reasons hold God or a transcendent power responsible for poverty, considering it as a test or punishment (Sterkens et al. 2019). People may have other reasons to explain the poverty of their neighbors; yet, all these attributions have one thing in common: They do not hold me responsible for poverty; neither do they urge me to take responsibility for it. Such lack of accountability may be one of the reasons for the dearth of enthusiasm for justiciability of economic human rights.

On the other hand, as O'Connell (2011) warns, neo-liberalism can recast socioeconomic rights in 'market friendly' terms favoring deregulation and competitiveness of transnational economic elites. Under the pressure of the neo-liberal political agenda even the national courts can give in to adjusting the domestic constitutional provisions for providing agreeable judicial interpretation of socioeconomic rights; this can be further compounded by judicial globalization at the service of the multinationals.

\subsection{Socioeconomic Rights in Indian Constitution}

Although the Indian constitution adopted in 1950 does not explicitly recognize the socioeconomic rights, they are said to be inferable from the right to life and are acknowledged in the Directive Principles of State Policy (Part IV of the Constitution). Article 43 (Part IV) of the Indian Constitution reads: "The State shall endeavor to secure, by suitable legislation or economic organization or in any other way, to all workers, agricultural, industrial or otherwise, work, a living wage, conditions of work ensuring a decent standard of life, and full enjoyment of leisure and social and cultural opportunities and, in particular, the State shall endeavor to promote cottage industries on an individual or co-operative basis in rural areas." As the volumes edited by Singh (2009) and Viswanathan (2008) attest, the debate on human rights and particularly on socioeconomic rights is rather vibrant in the Indian context. Socioeconomic welfare not only depends on the educational opportunities the young have for building up their capabilities, but also on not being excluded-on account of their caste, religion, or language-from participating in the political process of building up the common good.

In this regard, Hasan (2009) is of the view that politics of inclusion to accommodate the historically excluded groups in the public and decision making institutions has enabled them to articulate their interest in shaping the future of the nation. That is to say, reservations and affirmative actions ${ }^{7}$ by changing the balance of power in government and legislature, have contributed to a better democracy in India. In fact, the rise of Dalit politics-Dalits' assertion and mobilization-has irrevocably

7 In the Indian context 'reservation' can be understood as a political strategy to incorporate the historically disadvantaged groups into the mainstream of national life by a quota-based positive discrimination in sectors such as education, employment, and legislature; 'affirmative action' instead has a wider connotation, and extends from targeted intervention to preferential treatment (Hasan 2009, p. 16, note 9). 
transformed the Indian political landscape, particularly in Tamil Nadu (Gorringe 2005). Paradoxically, the reservation strategy also tends to prolong the discriminative caste system in subtle ways. Amidst such conundrums, can religious traditions play a role in the evolution of socioeconomic wellbeing? That is our concern in the next section.

\section{Religious Perspectives on Socioeconomic Wellbeing}

Centuries before the $\mathrm{CE}$, Buddhist monks reached out to the surrounding Asian regions through trade routes. Likewise, Hinduism, Christianity, and Islam have spread across the world along with traders. History attests to this close association between socioeconomic and religious sectors, with religious traditions at times evolving into socioeconomic and political power structures. Conversely, in the context of the current secularized world, economy, like politics, evolves as an autonomous sector driven by modern rationality and market dynamics. Even so, to the extent that religious traditions address the profound aspects of human life and its meaning, they continue to furnish a religio-ethical basis for socioeconomic wellbeing (Müller 1993; Hart 2007). This happens today particularly through educational institutions with the intent of making the young people authentic believers and responsible citizens. This is true for all three religions traditions of interest in this study, namely, Christianity, Islam, and Hinduism.

\subsection{Understanding of Socioeconomic Wellbeing in Christianity}

The prominence given to (theology of) the Roman Catholic Church in this study derives from the fact that it is the largest worldwide, as well as the largest Christian denomination in the Indian context. Christian roots are traceable to the well-established churches in Tamilakam (South India) no later than the beginning of the sixth century $\mathrm{CE}$; although the oral tradition pushes this further back to the arrival of St. Thomas the apostle about 52 CE (Neill 1984). Evidently, Christianity is not a monolithic religious tradition, for schisms and charismatic figures have given rise to numerous denominations and movements right through its history. Nevertheless, some tenets are common to most of them. The biblical understanding of the human being as created in God's image and likeness, the incarnation of the Son of God taking on the human nature with the view to making the divine life of God's Spirit accessible to human beings, provides the basis for the dignity of the human person (Brown 2007, pp. 217-19). For this reason, from the standpoint of the core Christian precept, upholding human rights is a response of love to God and to neighbors. Christian ethics in fact would demand that believers go beyond merely honoring others' socioeconomic rights (Irish 2003).

Even if the biblical tradition views burdensome manual labor as a consequence of disobedience to God, specific or professional work in the Christian tradition is deemed as a vocation for engaging the God-given talents, abilities, and wealth for responsibly building up the society, paying special attention to the poor and the marginalized (Brown 2007, pp. 236-40, 270-73). In this regard, the Catholic Church with papal encyclicals and exhortations, over a period of a century and a quarter, from Rerum Novarum (1891) of Pope Leo XIII to Laudato Sì (2015) of Pope Francis, has progressively built up a consistent body of social doctrine, addressing the emerging socioeconomic and environmental issues from an ever-widening perspective. The tradition consolidated by the Pontifical Council for Justice and Peace (2004) in the Compendium of the Social Doctrine of the Church marks a significant contribution of the Catholic Church in this regard (Quinn 2003).

Without going into the chronological development of the Catholic social doctrine, we may just mention the concern of the recent documents. In Caritas in Veritate (2009), Pope Benedict XVI offers a theological framework for the social doctrine, underscoring environmental concerns and intergenerational justice. In Evangelii Gaudium (2013), Pope Francis denounces the economy of exclusion and consumerism, whereas in Laudato Si (2015) he takes up the environmental crisis and laments that 
progress in science and technology has not been matched by moral, ethical, and spiritual growth. ${ }^{8}$ Mindful of the COVID-19 pandemic that disrupts the life of those engaged in non-formal working conditions or the grassroots' economy—taking the cue from Pope Leo XIII—the current pope has voiced the urgency of adopting universal basic income. ${ }^{9}$

In this vein, the social doctrine of the Church addresses a wide range of issues such as the merits and shortcomings of various economic systems and theories; the import of work, unemployment, and child labor; the economic implications of charity, justice, and rights; the morality of wages, working conditions, unions, strikes, and co-partnership; and the role of the Church and the State in the sphere of private and public education (Schuck 1994, pp. 611-34). The modern social doctrine of the Church largely draws attention to what has come to be known as the second generation of human rights, namely, the socioeconomic rights (Fredericks 2015, pp. 109-10, 114). A detailed analysis (Anthony et al. 2020) brings to light that there is a great deal of overlap between the social doctrine of the Catholic Church — shared in varied ways by the other Christian denominations-and the socioeconomic human rights culture. This explains why we have not gone into the positions held by various Christian Churches.

\subsection{Understanding of Socioeconomic Wellbeing in Islam}

It is significant that the central figure of Islam, namely, Prophet Muhammad, was a merchant and the city of his birth, Mecca, was a center of international caravan trade. He was hired by a successful businesswoman Khadija-later his wife-to manage her trade. If the traditional Muslim cities were built around the mosque with the learning centers close to it, the array of streets that radiated from the mosque led to the commercial centers or bazaars. Already in the pre-modern times, trade flourished through the two well-established routes: The Silk Road and the trans-Sahara caravan route. These attest to the extent the socioeconomic aspects of life were integrated with the religious-spiritual aspects of Islam, upholding work as an honorable aspect of day-to-day living. The wealth resulting from work and trade was to be shared-through the so-called system of zakat (i.e., act of giving incumbent on Muslims) and sadaqa (i.e., charitable act of giving)—with those in need on the ground of compassion and social justice for strengthening the community. This follows from the divine cosmic design of all natural resources belonging to God with human beings having a special place as Khalifah (vicegerent) to create conditions for a dignified life. While wealth is a blessing, it also brings with it the ethical and social responsibility of using it to meet one's own needs, without ignoring that of the community; for the trusteeship of wealth and property calls for accountability (Nanji 2007, pp. 287-90, 307-10).

In this sense, Islamic tradition establishes a dynamic rapport between the realm of faith (din) and the realm of human affairs (dunya). The moral significance of human life (taqwa) underscores the responsibility of the individual to God and to society (Nanji 2007, pp. 283-88). "Human beings are amongst God's most noble creation and have a special place within the created order. As part of a pluralistic world community, this common origin and innate human dignity offers the possibility that no matter what the material conditions of life, their ethical life is to be governed by moral reasoning, choice and accountability" (ibid p. 287). This would imply avoiding 'riba,' namely, usurious practice of moneylenders rather common when Islam appeared in the Arabian Peninsula. With the view to overcoming a practice that affected mostly the poorer section of the society, some Muslim countries have evolved the system of Islamic Banks on the basis of 'profit sharing,' leasing, or long-term credit (Shaghil 1999, pp. 114-16; Nanji 2007, p. 309). In other words, even if private use of resources is possible, a believer cannot ignore the common good in a universal perspective paying special attention to the poor and the ecological crisis. This would require a 'global economics' that brings together

8 For the documents of the Catholic Church see http://www.vatican.va/.

9 http://w2.vatican.va/content/francesco/en/letters/2020/documents/papa-francesco_20200412_lettera-movimentipopolari. html (accessed on 27 April 2020). 
the nation-states gradually into a 'one world' structure for regulating the collective use of resources. The United Nations Organization and the convergence on human rights may be considered as a step in tune with the Islamic universalism of ensuring justice, equity, and benevolent conduct (Shaghil 1999, pp. 116-18; Nanji 2007, pp. 329-31).

In some parts of the Muslim world, as in Indonesia, education of the young is combined with training for work-the so-called pesantren system. Such centers provide religious education, understanding of Islamic ethics, general and specialized knowledge related to crafts, agriculture, etc. In effect, Islamic tradition has given rise to a variety of educational institutions, such as jami (universities) and madrasas for higher learning. The madrasas are spread across the Muslim world, as centers for the instruction of language, Qur'anic studies, and Islamic law (Nanji 2007, pp. 303-5). The Islamic tradition —in its inner diversity — has given high priority to the pursuit of knowledge with the exercise of reasoning faculty, equating it with faith, if not just next to it. Advancement in knowledge in every field is viewed as the basis of socioeconomic development. For this reason, education is held as both an end in itself, and a means. Equal opportunity for participating in the economic activity with innovative capacity would require that all have free access to education (Shaghil 1999, pp. 120-22).

\subsection{Understanding of Socioeconomic Wellbeing in Hinduism}

In the ancient Indian society, wealth was considered desirable for the realization of full and civilized life, whereas poverty was viewed as 'living death.' However, artha (wealth) was only one of the goals of human life, the other three being dharma (righteousness), kama (pleasure), and moksha (liberation). The ultimate goal of supreme liberation is to be reached through righteous means of seeking wealth and enjoyment. Ensuring the means of living through honest work is acknowledged as an intrinsic feature of human wellbeing (Antoine 1968a, p. 115).

These goals have their significance as the individual goes through four stages of life, the first of which is brahmacharya (bachelor), namely, that of pupil or student. It is the stage in which the young dedicate their energy and effort to learning and shaping their character under the guidance of gurus (educators). This formation stage prepares the young person to the next stage of married life, grihastha (householder), requiring not only the maintenance of the family, but also participation in the development of the society. Such a stage of seeking wealth and enjoyment through righteous actions is crucial to socioeconomic wellbeing. When one's own children have reached the householder stage with families of their own, the elderly person is to enter the retiring stage of vanaprastha (forest-dweller). At this stage, the individual withdraws from the active involvement in the socioeconomic sphere and focuses his/her attention on the spiritual goal of moksha (liberation/salvation). Abandoning all concerns of earthly matters leads one to the final stage of samnyasi (renouncer). In this way, Hindu tradition does not negate the socioeconomic responsibility of the individual, yet it does not consider wealth and enjoyment as the only or ultimate scope of human wellbeing (Menski 2007, pp. 3-5; Antoine 1968b, pp. 120-22).

Among the still prevailing caste divisions, Brahmins and Kshatriyas-the former competent in religious knowledge and rituals, and the latter in protecting and governing the society-were not so much involved in the productive activities; these were the exclusive prerogative of the Vaishyas. Agriculture, cattle tending, and trade, even maritime trade-as we mentioned earlier-were the basis of economy (Raychoudhary 1989, pp. 198-213). The division of labor according to the caste system - rather discriminative in nature as it left the menial jobs to the Shudras and outcastes-did favor the transmission of experience and skill of the specific sector to the new generations within the family and clan. In the contemporary democratic context, although anyone can be an entrepreneur, there is no doubt that those from Vaishya caste find the support system needed to be involved in the business and industrial sector (Das 2007, pp. xiii, 139-54; Antoine 1968b, pp. 118-20).

In the Hindu tradition, human life and wellbeing are regulated by the law of Karma (fruits of the action) and the cycle of Samsara (rebirth). Productive action, and any human action for that matter, has its good or bad effects. Such effects or fruits are to be enjoyed or endured in the present, if not in 
the next life. There is no escape; it is an inevitable necessity. It means that action leads to a cycle of rebirths in order to enjoy or suffer the consequence of one's action. Only by renouncing the fruits of one's action, i.e., by non-attachment (nishkama karma), can one escape the cycle of births, achieve moksha or liberation. Besides this karma marga (path of action), Hindu tradition also proposes according to the predisposition of persons, jnana marga (path of knowledge) and bhakti marga (path of devotion) to reach the ultimate goal of moksha. Whether it be productive action, intellectual pursuit, or devotional engagement, the essential is to renounce one's self and the fruits of one's action (Antoine 1968a, pp. 112-14).

The foregoing features of Hindu tradition rest on the view that the three poles of the reality, God-Man-Cosmos, are interrelated and interdependent. Such constitutive correlation implies that human wellbeing in reality is a cosmotheandric experience, a cosmotheandric embrace (Panikkar 1993). It means that human productive action cannot ignore the creation as a partner in the journey of life. The principle of interdependence lays emphasis not so much on being autonomous individuals as on being part of a cosmic whole (Anthony 2014; Sontheimer 1993; Basu 1990). Even so, in contrast to the veritable reality of the Transcendent, the material realities are deemed as mere maya (illusion). For what appears to be the obvious reality in fact is held in existence by That which is Existence itself (sat-chit-ananda, existence-consciousness-bliss). Evidently, Hinduism is not a monolithic tradition; the immense diversity that goes to make the encyclopedia of Hindu traditions, however, do make some reference implicitly or explicitly to the framework of basic concepts—presented above-in dealing with the socioeconomic aspects of human wellbeing.

\section{Conceptual Model and Research Questions}

Our intention in this study is to explore the impact of religions on socioeconomic rights in the pluralistic and democratic Indian context. The religious visions-briefly expounded above-can play their inspirational role with reference to human rights at three different levels of ethical discourse: Meta-ethical discourse, normative ethical discourse, and legal ethical discourse. While meta-ethical discourse deals with religious or transcendent foundations of human dignity, normative ethical discourse seeks to clarify the criteria for evaluating human action, and legal ethical discourse focuses on social and legal practices (Magni 2011, pp. 43-46). We can then examine the impact of religions at meta-ethical, normative ethical, and legal ethical levels.

The meta-ethical discourse deals with religious or transcendent foundations of human dignity; and as such, it stands for the religious legitimation of human rights. According to van der Ven et al. (2004, pp. 261-303) religious legitimation or meta-ethical discourse may be viewed from internal (ad intra) and external (ad extra) perspectives. From an internal perspective, the religious legitimation can evolve "in terms of" and "with the view to." In the first case, the religious traditions can shed light on the meaning and foundation of human rights in terms of metaphors, symbols, and theories specific to each. In the second case, religious traditions can nourish and legitimize human rights culture with the view to promoting the latter among the believers. In this vein, the ad extra dimension of religious legitimation would refer to its contribution to the public arena, engaging disciplines such as philosophy, sociology of law, and jurisprudence. It could also encompass dialogue with other non-religious and religious interpretations of human rights. Thus, religious legitimation can contribute to opinion formation in the civil society, as well as nurture human rights culture and advocacy within the religious community. In our research, at the meta-ethical level, we have taken into account personal religious attitudes and contextual religious attitudes, together with the process of religious socialization.

The normative ethical discourse associated with religious traditions seeks to clarify the criteria for evaluating human action. As there are different normative ethical currents, the criteria for evaluating human action may differ according to currents such as ethics of consequences, deontological ethics, and ethics of virtues (Magni 2011). The religious traditions, in our case, Christianity, Islam, and Hinduism, have in the course of their history each built up a body of normative ethical and moral discourse. The legal ethical discourse associated with religious traditions focuses on social and 
legal practices. This would necessitate addressing the legal practices associated with the religious traditions, namely, the complexity arising from personal law system linked to Christian, Muslim, and Hindu communities in the Indian context (Anthony and Sterkens 2019b). Insofar as normative ethical discourse is the basis for legal ethical discourse, in the present research we have represented them as ethical discourse underlying the experience of democracy, namely, value of human dignity, functioning of the state, satisfaction with national life, and at a more personal level, the configuration of psychosocial and socio-political traits.

Thus, in order to examine the impact of religion on the levels of agreement with socioeconomic human rights, we specify religion in terms of concrete religious attitudes. We distinguish between personal and contextual religious attitudes. In our case, personal religious attitudes comprise cognitive (e.g., beliefs about God), affective (e.g., religious experiences), and operative dimensions (e.g., religious practices). Contextual religious attitudes refer to the interaction between religions, and between religion and society. More precisely, contextual attitudes include convictions about how one's own religion relates to that of others, trust in one's own religion and in that of others, and the public function of religion. The religious socialization of the respondents can also be related to the degree of support for such rights. Therefore, we deem family/peer religious influence and interreligious contacts to be part of independent variables. Insofar as values underlying democracy are crucial to socioeconomic rights, we have included the values of human dignity, functioning of the state, and satisfaction with national life. Thus, the list of independent variables in our conceptual model (see Figure 1) comprises personal religious attitudes (religious beliefs, experiences, and practices) and contextual religious attitudes (function of religion, religious pluralism, trust in religions), religious socialization, and experience of democracy.

\begin{tabular}{|c|c|c|}
\hline Background variables & Independent variables & Dependent variables \\
\hline $\begin{array}{l}\text { Personal profile } \\
\text { - } \quad \text { Age } \\
\text { - } \quad \text { Sex } \\
\text { - } \quad \text { Educational level of parents } \\
\text { Psychosocial traits } \\
\text { - } \quad \text { Right-wing authoritarianism } \\
\text { - } \quad \text { Social dominance orientation } \\
\text { - } \quad \text { Empathy } \\
\text { Socio-political traits } \\
\text { - } \quad \text { Multiculturalism } \\
\text { - } \quad \text { Political orientation }\end{array}$ & $\begin{array}{l}\text { Personal religious attitudes } \\
\text { - } \quad \text { Religious beliefs } \\
\text { - } \quad \text { Religious experiences } \\
\text { - } \quad \text { Religious practices } \\
\text { Contextual religious attitudes } \\
\text { - } \quad \text { Function of religion } \\
\text { - } \quad \text { Religious plurality } \\
\text { - } \quad \text { Trust in religions } \\
\text { Religious socialization } \\
\text { - } \quad \text { Parents' influence } \\
\text { - } \quad \text { Peer influence } \\
\text { - } \quad \text { Interreligious contact } \\
\text { Experience of Democracy } \\
\text { - } \quad \text { Value of Human dignity } \\
\text { - } \quad \text { Functioning of the State } \\
\text { - } \quad \text { Satisfaction with national life }\end{array}$ & $\begin{array}{l}\text { Socioeconomic rights } \\
\text { - } \text { Right to work } \\
\text { - } \quad \text { Right to living wages } \\
\text { - } \quad \text { Right to social security } \\
\text { - } \quad \text { Right to rest and leisure } \\
\text { - } \quad \text { Right of children } \\
\text { - } \quad \text { Right of religion in } \\
\text { education }\end{array}$ \\
\hline
\end{tabular}

Figure 1. Conceptual model: Socioeconomic rights (dependent variables) and religious attitudes and socialization, and experience of democracy (independent variables) and personal profile and traits (background variables).

Background variables taken into account are personal profile, psychosocial traits, and socio-political traits, which could influence the attitudes concerning socioeconomic rights. The personal characteristics 
relevant to our research are age, gender, and educational level of parents, because they can influence the view on socioeconomic rights in different ways. Finally, we have included the respondents' psychosocial traits as background variables: Psychological characteristics and ideas about society, as well as cultural and political orientations that could influence the moral evaluation of socioeconomic rights. The list of psychosocial traits includes tendencies concerning authoritarianism, social dominance, and empathy; and that of socio-political traits, tendencies concerning multiculturalism, and political orientation.

As shown in Figure 1, the conceptual model underlying our empirical study on the impact of religion on socioeconomic rights comprises three sets of variables: Attitudes concerning socioeconomic rights (dependent variables); personal and contextual religious attitudes, religious socialization, and experience of democracy (independent variables); and personal characteristics, psychosocial and socio-political traits (background variables).

The conceptualization and operationalization of these variables focused on socioeconomic rights is part of the International Religion and Human Rights research project (2013-2020) coordinated by Professor Hans-Georg Ziebertz of Würzburg University. We therefore limit ourselves to a synthetic presentation of the operationalization of the concepts in the next section. Our overall aim is to understand the relationship between religion and attitude towards socioeconomic rights among the young people living in the Indian pluralistic and democratic context. Do their religious traditions make a difference in what they think about socioeconomic issues? We specify this research problem in the following research questions:

(1) What understanding of socioeconomic rights emerges among our respondents?

(2) Are there significant differences in the students' attitudes towards socioeconomic rights based on their religious affiliation?

(3) Which independent variables (personal and contextual religious attitudes, religious socialization, and experience of democracy) correlate with attitudes towards socioeconomic rights among Christians, Muslims, and Hindus?

(4) Which background variables (personal profile, and psychosocial and socio-political traits) correlate with attitudes towards socioeconomic rights among Christians, Muslims, and Hindus?

(5) Which independent variables (personal and contextual religious attitudes, religious socialization, and experience of democracy) and background variables (personal profile, and psychosocial and socio-political traits) emerge as predictors of agreement with socioeconomic rights among Christians, Muslims, and Hindus?

\section{Research Design}

In this section, we first briefly sketch the sample and the process of data collection, before proceeding to the instruments we used, and finally to the statistical methods we chose for data reduction and analysis.

\subsection{Sample and Data Collection}

With the view to examining students' socioeconomic attitudes and how these may be influenced by their attitudes towards religion and democracy, we draw on the data collected in Tamil Nadu, for the Religion and Human Rights research project (2013-2020) mentioned above. We decided to contact around 1200 respondents among whom men and women, and the three religious traditions were equally represented; and hence used a stratified quota sampling with random selection of respondents in each stratum. The respondents of the study primarily included undergraduate students of seven arts and science colleges. Two colleges were chosen from each of the three regions and one from the State capital of Tamil Nadu, resulting in the following number of respondents for the different regions: Northern region (308), western region (304), southern region (303), and Chennai (300). The total sample comprised 1215 respondents: 407 Christians (of whom 387 were Catholics), 408 Muslims, and 400 Hindus. There were 614 male and 601 female respondents. The educational levels of their parents 
give us an inkling into their socioeconomic status: Only $7.1 \%$ of the mothers and $14.3 \%$ of the fathers have Bachelor's, Master's, or other higher qualification than the school education. It means that our respondents mostly belonged to the lower middle-class families. As for their age, they mostly belonged to the age group 17 to 20 years. This is a suitable age group to study the socioeconomic attitude, as these young people prepare themselves to enter the professional and social life.

\subsection{Measuring Instrument}

The questionnaire (in accessible English) was designed by a group of international scholars involved in the Religion and Human Rights research project (2013-2020) with the hope that at least some aspects of the findings could be relevant for comparing trends among young people of different countries and religious traditions. It addressed a wide range of human rights: Right to life (Anthony and Sterkens 2019a), judicial rights (Anthony and Sterkens 2019b), political rights (Anthony and Sterkens 2018), civil rights (Anthony and Sterkens 2016), and socioeconomic rights that constitute the dependent variables in the present study. Socioeconomic attitudes are operationalized in terms of twelve items (Table 1): State's obligation regarding right to work (item a and h), right to social security (item $b$ and $k$ ), right to living wages (item $\mathrm{c}$ and g), right to rest and leisure (item $\mathrm{d}$ and l), right of children (item e and $\mathrm{i}$ ), and right of religion in education (item $\mathrm{f}$ and $\mathrm{j}$ ). Our respondents expressed their disagreement or agreement on a five-point Likert scale, with midpoint indicating uncertainty.

Four sets of independent variables were operationalized in the questionnaire: Personal religious attitude, contextual religious attitude, religious socialization, and experience of democracy. An essential aspect of personal religious attitudes, namely, religious beliefs can be understood to focus on the transcendent being or God. In the first place, it concerns the belief in the existence of God; such a belief can refer to a personal God or to a non-personal God. The belief in personal God can be represented in terms of theism, pan-en-theism, and natural pan-en-theism. Instead, the belief in a non-personal God can be represented in terms of deism, pantheism, and meta-theism. Factor analysis of these beliefs results in two factors, namely, belief in personal God and belief in non-personal God. ${ }^{10}$ In the context of religious beliefs, we found it opportune to verify-with an item-how critical one is of the religious teachings that one in principle agrees with.

Based on the contemporary distinction between religion and spirituality, religious experience in our questionnaire was represented as faith experience and spiritual experience. However, factor analysis brought spiritual experience and faith experience into one meaningful and reliable factor, 'religious experience. ${ }^{\prime 11}$ This is significant in a profoundly religious Indian context attentive to spiritual experience. A critical note on this - with an item-is meant to verify the experience of divine intervention in one's life. Religious practice in the specific sense has been limited to verifying the frequency of prayer and participation in religious services. A critical note in this regard refers to the influence of religion on one's daily life. In this vein, some wider aspects of religious practice in daily life have been subsumed in the contextual features.

Among the contextual religious attitudes, our research took into account three sets of variables: Function of religion in society, approach to religious pluralism, and trust in one's own and others' religion. The functions of religion taken into account were related to public opinion, national culture, prophetic voice, spiritual service, and cultural conformity. Factor analysis of the eight items evinced factors representing two meaningful functions of religion, namely, 'integral transformative function'

10 All these independent variables—except for those consisting of single items-are results of rigorous procedure of factor analyses. However, we do not report on the factor analyses of the independent variables, except for two cases where new configurations emerge: Religious experience, and integral transformative and cultural conformity functions.

11 Factor analysis brought the two items representing spiritual experience (i.e., people say that they have had an experience of profound inner peace; that they have had an experience of oneness with all things) and the two representing faith experience (i.e., people say that their faith has often helped them not to lose courage in particular situations; that their religion gives them a certainty in life that they otherwise would not have) into one meaningful and reliable factor 'religious experience' $(\alpha 0.72)$. 
and 'cultural conformity function.' 12 In a pluralistic context, the followers of various traditions may take broadly two approaches as to how these contribute to a flourishing life: Exclusivism as affirming the singularity of one's religion, and pluralism as appreciation of other religions in this regard. A multi-religious context brings into question not only how one may interpret another religion, but also the trust one may place in one's own religion and in others' religion. Variables related to religious socialization taken into account in our research include the influence of parents, peer group, and persons affiliated to other religious traditions.

Besides the foregoing independent variables concerning religious pluralism, our research includes those regarding the experience of democracy. The value of human dignity as the basis of democracy has been considered from three different perspectives: As resulting from dignity of merit, as depending on the moral behavior of persons, and as expression of human beings' intrinsic worth. Moreover, democracy has been represented with reference to the functioning of the state and the satisfaction with national life.

Among the background variables, other than the personal profile of age, sex, and educational level of parents, psychosocial traits, such as right-wing authoritarianism, social dominance orientation, and empathy have been taken into account. Likewise, socio-political traits of multiculturalism and political orientation have been viewed as relevant to the religion and human rights rapport.

\subsection{Methods of Analysis}

With the view to verifying the respondents' tendency with regard to socioeconomic rights, descriptive analysis and factor analysis were undertaken. Two reliable factors of socioeconomic rights emerged. To test for significant differences between Christian, Muslim, and Hindu students in their socioeconomic attitudes, Scheffé's tests were employed. Correlation analyses evinced some strong and moderately strong correlations (Pearson's $r$ ) of independent variables related to religion (personal and contextual religious attitudes, and religious socialization) and democracy (value of human dignity, functioning of the state, and satisfaction with national life) with socioeconomic rights. Similarly, correlation analyses were employed to elucidate the associations of personal profile, psychosocial and socio-political traits with socioeconomic rights.

Finally, with the view to identifying the predictors of socioeconomic rights attitude, three regression analyses were undertaken with independent and background variables. In the first regression analysis, independent and background variables were inserted if they showed moderate correlation $(r \geq 0.15)$ with socioeconomic rights in at least one of the religious groups. In the second regression analysis, the variables were inserted if they had shown a significant contribution in the explanation of socioeconomic rights in the first regression analysis. Insignificant predictors in the initial regression analysis were removed in the second regression analysis. In the third and final regression analysis (Table 5), the additional insignificant predictor 'exclusivism' from the second regression analysis was removed.

\section{Empirical Results}

Following the order of the five research questions, we first analyze the respondents' tendencies concerning socioeconomic rights, and then examine the relation between these and their religious attitudes, experience of democracy besides background characteristics.

Research question 1: What understanding of socioeconomic rights emerges among our respondents?

12 The integral transformative function included six items $(\alpha 0.69)$ : Religions should try to influence public opinion on social problems; should publicly stand up for the underclass; should take joint responsibility with the state for the national culture; should take public responsibility for the societal development; should take responsibility for their members' spiritual growth; and should create places for deep spiritual experiences. The cultural conformity function $(\alpha 0.39)$, instead, included two items: Religions should always keep up with current social trends; and should go along with changing ideas in the society. 
Descriptive statistics (mean and standard deviation) on item level brings to light the general tendency among our respondents. As can be seen in Table 1, our respondents tend to agree with all the 12 items. However, we find that least agreement is shown concerning right of religion in schools: Right of religions to establish schools (item $\mathrm{f}$ : Mean 3.66) and religion to be taught in schools (item j: Mean 3.47). Agreement is rather weak also with regard to the following two items: Right to periodic holidays for temporarily hired workers (item 1: Mean 3.71) and decent standard of living for the unemployed (item h: Mean 3.67).

Table 1. Number of respondents, means, and standard deviations of items about socioeconomic rights in descending order of average agreement (items a-1).

\begin{tabular}{|c|c|c|c|}
\hline & $\mathbf{N}$ & Mean & s.d. \\
\hline a. The government should provide a job for everybody who wants one. & 1212 & 4.01 & 1.22 \\
\hline e. The state should be obliged to protect children from forced child labor. & 1207 & 4.01 & 1.26 \\
\hline k. The government should provide a decent standard of living for the old. & 1212 & 4.00 & 1.10 \\
\hline i. The state should be obliged to protect children's right to engage in play and recreation. & 1209 & 3.93 & 1.17 \\
\hline c. Everyone should have the right to equal pay for equal work. & 1213 & 3.90 & 1.25 \\
\hline 1. Hiring people for salary or hourly work without periodic holidays paid for should be forbidden. & 1211 & 3.71 & 1.31 \\
\hline
\end{tabular}

Interpretations of means: 1.00-1.79: Total disagreement; 1.80-2.59: Disagreement; 2.60-2.99: Negative ambivalence;

3.00-3.39: Positive ambivalence; 3.40-4.19: Agreement; 4.20-5.00: Full agreement.

As for the other eight items dealing with social security for the sick and the old (items b and k), rights of children to be free of labor and to recreation (items e and $i$ ), the right to reasonable and equal wages (items $\mathrm{c}$ and g), right to work (item a), and to rest (item d), the respondents' levels of agreement is rather high (mean scores between 3.90 and 4.09).

As shown in Table 2, factor analysis of the 12 items (PAF, oblimin rotation) reveals two rather reliable factors explaining a total variance of $35.26 \%$. Factor 1, representing 'Socioeconomic rights' includes the eight items manifesting higher agreement tendency in the descriptive analysis. The reliability of the factor is rather high $(\alpha 0.81)$. Yet, two items referring to periodic holidays for temporarily hired workers and decent standard of living for the unemployed do not load on this factor. Probably students view these as suitable for welfare states, and not for a developing country like India.

Factor 2, 'Religion's right in education' comprises the two items with the least agreement tendency (item $\mathrm{j}$ and $\mathrm{f}$ ). Although religious traditions in varying ways have given origin to the educational system for religious and moral formation of the young to take their place in the society, given that the reliability $(\alpha 0.48)$ of the second factor is modest, and that it does not explicitly focus on socioeconomic rights, we shall not consider it in the successive analysis. These items may fit better as part of civil rights, and more specifically of freedom of religion. 
Table 2. Factor analysis (PAF oblimin rotation), communalities $\left(\mathrm{h}^{2}\right)$, percentage of explained variance, and reliability (Cronbach's alpha) of socioeconomic rights for all respondents.

\begin{tabular}{lccc}
\hline & F1 & F2 & h $^{\mathbf{2}}$ \\
\hline a. The government should provide a job for everybody who wants one. & 0.672 & -0.052 & 0.42 \\
\hline g. Everyone should have the right to just and reasonable pay for work performed. & 0.643 & -0.102 & 0.36 \\
\hline i. The state should be obliged to protect children's right to engage in play and recreation. & 0.640 & -0.081 & 0.37 \\
\hline b. The government should provide health care for the sick. & 0.547 & 0.187 & 0.43 \\
\hline k. The government should provide a decent standard of living for the old. & 0.545 & 0.065 & 0.34 \\
\hline c. Everyone should have the right to equal pay for equal work. & 0.543 & 0.077 & 0.34 \\
\hline e. The state should be obliged to protect children from forced child labor. & 0.507 & 0.023 & 0.27 \\
\hline d. Everyone should have the right to reasonable limitation of working hours to get enough rest. & 0.466 & 0.214 & 0.36 \\
\hline j. The government should provide for enough space that religion could be taught in schools. & -0.041 & 0.600 & 0.34 \\
\hline f. The state should respect the right of religions to establish schools. & 0.147 & 0.464 & 0.30 \\
\hline Cronbach's alpha & 0.81 & 0.48 & 1215 \\
\hline Number of valid cases & 1215 & 1215 \\
\hline
\end{tabular}

Scale: $1=$ totally disagree; $2=$ disagree; $3=$ not sure; $4=$ agree; $5=$ fully agree. Explained variance $=35.26 \%$; $\mathrm{F} 1$ = Socioeconomic rights; F2 = Religion's right in education.

Research question 2: Are there significant differences in students' attitudes towards socioeconomic rights based on their religious affiliation?

Examining the responses of Christian, Muslim, and Hindu students (Table 3), we find that the three groups manifest clear agreement with regard to socioeconomic rights. However, Christian students express greater agreement (mean 4.16) and differ significantly (F-value: 18.62; $p<0.000$ ) from Muslims (mean 3.95) and Hindus (mean 3.84). For the young people in the educational process getting ready for the professional field, socioeconomic rights seem rather decisive. The small minority community of Christians seems more sensitive to these rights than those who belong to the larger Muslim and majority Hindu communities. We shall take up these findings for discussion in the final section.

Table 3. Levels of agreement (mean and standard deviation) with socioeconomic rights for Christians, Muslims, and Hindus and comparison of means between groups of respondents (Scheffé's test).

\begin{tabular}{lccccc}
\hline & N & Mean & s.d. & Muslims & Hindus \\
\hline Christians & 407 & 4.16 & 0.73 & $* *$ & $* *$ \\
Muslims & 408 & 3.95 & 0.85 & & \\
Hindus & 400 & 3.84 & 0.70 & & \\
\hline
\end{tabular}

Interpretations of means: 1.00-1.79: Total disagreement; 1.80-2.59: Disagreement; 2.60-2.99: Negative ambivalence; 3.00-3.39: Positive ambivalence; 3.40-4.19: Agreement; 4.20-5.00: Full agreement. Intergroup differences are significant at $p<0.01\left(^{* *}\right)$. Scheffé's test: F-value: 18.62; significance $<0.000$.

Research question 3: Which independent variables (personal and contextual religious attitudes, religious socialization, and experience of democracy) correlate with socioeconomic rights among Christians, Muslims, and Hindus?

Correlational analyses (Table 4) bring to light a number of associations of independent variables of religion and democracy with socioeconomic rights for each of the three religious groups. We shall comment only on the strong and the moderately strong correlations. 
Table 4. Correlations (Pearson's r) between socioeconomic rights and personal and contextual religious attitudes, religious socialization, and experience of democracy for the three religious groups.

\begin{tabular}{|c|c|c|c|}
\hline & \multicolumn{3}{|c|}{ Socioeconomic Rights } \\
\hline & Christians & Muslims & Hindus \\
\hline \multicolumn{4}{|l|}{ Personal religious attitudes } \\
\hline \multicolumn{4}{|l|}{ Religious belief } \\
\hline Belief in personal God & $0.62 * *$ & $0.48^{* *}$ & $0.27 * *$ \\
\hline Belief in non-personal God & 0.61 ** & $0.47^{* *}$ & $0.29 * *$ \\
\hline Belief in the existence of God & $0.29 * *$ & $0.42 * *$ & - \\
\hline Critical approach to religious belief & - & $0.24 * *$ & - \\
\hline \multicolumn{4}{|l|}{ Religious experience } \\
\hline Religious experiences & $0.44^{* *}$ & $0.33^{* *}$ & $0.21 * *$ \\
\hline Experience of divine intervention & $0.33 * *$ & $0.40^{* *}$ & - \\
\hline \multicolumn{4}{|l|}{ Religious practice } \\
\hline Frequency of prayer & $0.22 * *$ & $0.26^{* *}$ & - \\
\hline Participation in religious service & $0.18^{* *}$ & - & $0.11 *$ \\
\hline Influence of religion on daily life & - & $0.24^{* *}$ & - \\
\hline \multicolumn{4}{|l|}{ Contextual religious attitudes } \\
\hline \multicolumn{4}{|l|}{ Function of religion } \\
\hline Integral transformative function & $0.30 * *$ & $0.52 * *$ & $0.29 * *$ \\
\hline Cultural conformity function & - & - & $0.12 *$ \\
\hline \multicolumn{4}{|l|}{ Religious plurality } \\
\hline Exclusivism & $0.17 * *$ & $0.41 * *$ & $0.14 * *$ \\
\hline Pluralism & $0.26 * *$ & $0.25 * *$ & $0.16^{* *}$ \\
\hline \multicolumn{4}{|l|}{ Trust in Religion } \\
\hline Trust in in-group & $0.20 * *$ & $0.26^{* *}$ & $0.18 * *$ \\
\hline Trust in out-group & $-0.15^{* *}$ & $-0.23^{* *}$ & - \\
\hline \multicolumn{4}{|l|}{ Religious socialization } \\
\hline Father's belief and faith & $0.30 * *$ & $0.36^{* *}$ & - \\
\hline Mother's belief and faith & $0.29 * *$ & $0.30 * *$ & $0.15 * *$ \\
\hline Father expectation to adopt faith & $0.30 * *$ & $0.35^{* *}$ & $0.15^{* *}$ \\
\hline Mother expectation to adopt faith & $0.20 * *$ & $0.31 * *$ & $0.13 * *$ \\
\hline Best friend's belief and faith & $0.36^{* *}$ & $0.25 * *$ & $0.16^{* *}$ \\
\hline Interreligious contact & $0.27^{* *}$ & $0.16^{* *}$ & $0.15^{* *}$ \\
\hline \multicolumn{4}{|l|}{ Experience of Democracy } \\
\hline \multicolumn{4}{|l|}{ Value of human dignity } \\
\hline Dignity of merit & $0.10 *$ & $0.24^{* *}$ & - \\
\hline Moral dignity & $0.32 * *$ & $0.33^{* *}$ & $0.17 * *$ \\
\hline Intrinsic dignity & $0.17^{* *}$ & $0.27^{* *}$ & - \\
\hline \multicolumn{4}{|l|}{ Functioning of democracy } \\
\hline Legislative power & $0.12 *$ & - & $0.11 *$ \\
\hline Administrative power & $-0.14^{* *}$ & - & - \\
\hline Judicial power & - & - & - \\
\hline Police treatment of people & $-0.13 * *$ & & \\
\hline \multicolumn{4}{|l|}{ Satisfaction with national life } \\
\hline With life as a whole & - & - & - \\
\hline With recent state of economy & - & $-0.11 *$ & - \\
\hline With the government & $-0.13^{* *}$ & - & - \\
\hline With the way democracy works & - & - & - \\
\hline With the state of education & - & - & - \\
\hline With the state of health services & $-0.12 *$ & - & - \\
\hline
\end{tabular}

Correlations are significant at $p<0.00{ }^{* *}$ ) or $p<0.05\left(^{*}\right)$ level (2-tailed). Only significant correlations are indicated. Interpretation of correlations: Weak $(r<0.15)$, moderately strong $(0.15 \leq \mathrm{r}<0.30)$, and strong $(\mathrm{r} \geq 0.30)$.

Examining the personal religious attitudes, we find that belief in personal God relates strongly with socioeconomic rights in the case of Christians ( $\mathrm{r}$ 0.62) and Muslims (r 0.48), and moderately strong for Hindus ( $\mathrm{r}$ 0.27). This is true also in the case of belief in non-personal God for the three groups: Very strong for Christians (r 0.61) and Muslims (r 0.47), and moderately strong for Hindus (r 0.29). 
Instead, belief in the divine existence has a moderately strong association for Christians (r 0.29) and strong association for Muslims (r 0.42). Remarkably, the belief system of the three religious traditions has substantial positive relationships with socioeconomic attitudes. Moreover, in the case of Muslims, critical approach to belief also manifests a moderate association (r 0.24).

With regard to religious experience, we find strong associations with socioeconomic rights in the case of Christians (r 0.44) and Muslims (r 0.33), and moderately strong association in the case of Hindus (r 0.21). Likewise, experience of divine intervention presents strong correlations for Christians (r 0.33) and Muslims (r 0.40). Thus, we find that some aspects of religious experience are significant particularly in the case of Christians and Muslims in their approach to socioeconomic rights. Probably, for Hindus religious experience does not concern the material aspects.

Considering the religious practice, we find that frequency of prayer manifests moderately strong association for Christians ( $\mathrm{r}$ 0.22) and Muslims (r 0.26), whereas participation in religious services has moderate influence on the socioeconomic attitude of Christians (r 0.18). Only for Muslims, influence of religion on daily life ( $\mathrm{r}$ 0.24) has moderately strong association with socioeconomic rights. Overall, personal religious attitudes seem to have more influence on the socioeconomic attitude of Christians and Muslims than of Hindus. Probably, the personal religious attitude of Hindus concerns less the socioeconomic aspects of life.

When it comes to contextual religious aspects, socioeconomic attitudes are strongly related to the integral transformative function of religion in the case of Muslims (r 0.52) and rather strongly in the case of Christians (r 0.30) and Hindus (r 0.29).

Considering the approaches to other religions, exclusivism has moderate association with socioeconomic rights for Christians (r 0.17), very strong association for Muslims ( $\mathrm{r}$ 0.41), and weak association for Hindus (r 0.14). Likewise, pluralism is moderately related to the socioeconomic attitudes among Christians (r 0.26), Muslims (r 0.25), and Hindus (r 0.16). Interestingly, openness to other religions is positively associated with socioeconomic rights, with exclusivism particularly favorable in the case of Muslims.

Examining the trust factor, we find that in-group trust manifests moderate relationship with socioeconomic rights among the three religious groups: Christians (r 0.20), Muslims (r 0.26), and Hindus ( $\mathrm{r}$ 0.18). In contrast, trust in out-groups manifests moderate negative associations for Christians $(\mathrm{r}-0.15)$ and Muslims ( $\mathrm{r}-0.23)$. For the minority groups, trusting one's own religion seems propitious for socioeconomic rights, while trust in out-groups is inversely related to these rights.

Remarkably, all aspects of religious socialization taken into account in our research have strong or moderately strong associations with socioeconomic rights in all three religious groups, but particularly among the religious minorities of Christians and Muslims. More specifically, in the case of Christians, father's belief (r 0.30), mother's belief (r 0.29), best friend's belief ( $\mathrm{r} 0.36$ ), and father's expectation that his faith be adopted ( $\mathrm{r}$ 0.30), have strong associations with socioeconomic rights, whereas mother's expectation (r 0.20) shows moderate correlation. In the case of Muslims, father's belief ( $\mathrm{r}$ 0.36), and his expectation that his faith be adopted ( $\mathrm{r} 0.35)$, mother's belief ( $\mathrm{r} 0.30)$, and mother's expectation that her faith be adopted ( $\mathrm{r}$ 0.31) are strongly related to socioeconomic rights, whereas best friend's belief ( $\mathrm{r} 0.25)$ has moderate association. For Hindus, only father's belief does not have any significant association, the other aspects have moderately strong associations: Mother's belief ( $\mathrm{r}$ 0.15), best friend's belief (r 0.16), father's expectation that his faith be adopted (r 0.15), and mother's such expectation (r 0.13). It must be mentioned that interreligious contact, in the case of the three religious groups, namely, Christians (r 0.27), Muslims (r 0.16), and Hindus (r 0.15), has moderately strong association with their socioeconomic attitudes. It is significant that in a multi-religious context religious socialization has its relevance for socioeconomic life. Moreover, the varying associations of religious attitudes and socialization among the three religious groups point to a certain complementarity between religious traditions and socioeconomic rights.

Examining the experience of democracy, we find that the value of human dignity deriving from merit has moderately strong association with socioeconomic attitude of Muslims (r 0.24). Instead, 
moral dignity shows strong correlation in the case of Christians ( $\mathrm{r}$ 0.32) and Muslims ( $\mathrm{r}$ 0.33), and moderate relationship in the case of Hindus ( $\mathrm{r}$ 0.17). Valuing the intrinsic human dignity is moderately related to socioeconomic rights for Christians ( $\mathrm{r}$ 0.17) and Muslims (r 0.27). It is significant that human dignity, intrinsic as well as that based on merit and morality, positively support socioeconomic rights, particularly among the religious minority groups in India, namely, Muslims and Christians.

Scrutinizing the working of the State, Christians' lesser satisfaction with the executive power $(\mathrm{r}-0.14)$, police treatment of people $(\mathrm{r}-0.13)$, and the government $(\mathrm{r}-0.13)$ relate to greater affirmation of socioeconomic rights. Surprisingly, except for the value of human dignity, the other facets of the functioning of democracy and national life do not seem to be relevant to the socioeconomic attitude of the young. We shall take up the significant findings related to the independent variables of personal and contextual religious attitudes, religious socialization, and experience of democracy in the last section.

Research question 4: Which background variables (personal profile, and psychosocial and socio-political traits) correlate with socioeconomic rights among Christians, Muslims, and Hindus?

Correlational analyses (Table 5) bring to light some associations of background variables of personal profile and psychosocial and socio-political traits with socioeconomic rights for each of the three religious groups. We shall comment only on the strong and the moderately strong correlations.

Table 5. Correlations (Pearson's r) between socioeconomic rights and background variables of the three religious groups.

\begin{tabular}{llll}
\hline & \multicolumn{3}{c}{ Socioeconomic Rights } \\
\hline & Christians & Muslims & Hindus \\
Personal profile & $0.13^{* *}$ & $-0.32^{* *}$ & - \\
$\quad$ Age & $0.11^{* *}$ & $-0.43^{* *}$ & - \\
$\quad$ Sex (female 1; male 2) & - & - \\
$\quad$ Educational level mother/father & - & $0.30^{* *}$ & $0.24^{* *}$ \\
Psychosocial traits & $0.14^{* *}$ & - & - \\
$\quad$ Right-wing authoritarianism & - & $0.40^{* *}$ & $0.33^{* *}$ \\
$\quad$ Social dominance orientation & $0.23^{* *}$ & & $0.21^{* *}$ \\
$\quad$ Empathy & $0.21^{* *}$ & $0.17^{* *}$ & $0.13^{*}$ \\
Socio-political traits & $-0.20^{* *}$ & - & \\
$\quad$ Multiculturalism & Political orientation & &
\end{tabular}

Correlations are significant at $p<0.00\left(^{* *}\right.$ or $p<0.05\left(^{*}\right)$ level (2-tailed). Only significant correlations are mentioned. Interpretation of correlations: Weak $(\mathrm{r}<0.15)$, moderately strong $(0.15 \leq \mathrm{r}<0.30)$, and strong $(\mathrm{r} \geq 0.30)$.

Examining the personal profile, we find that only in the case of Muslims, age and sex have strong associations with socioeconomic attitudes. Younger Muslims $(\mathrm{r}-0.32)$ and Muslim women $(\mathrm{r}-0.43)$ are more sensitive to socioeconomic rights than older Muslims and Muslim men. Probably this could be attributed to greater human rights awareness among the younger generation and the effect of education and feminism on Muslim women, or because of the relative vulnerable position of the latter. Contrary to our expectation, the educational level of parents that could represent their socioeconomic status does not correlate with socioeconomic rights for any of the religious groups.

The psychosocial trait of right-wing authoritarianism manifests rather moderate positive association with socioeconomic rights among Christians (r 0.14), and stronger correlation among Muslims ( $\mathrm{r} 0.30$ ) and Hindus (r 0.24). Similarly, empathy is positively associated with socioeconomic rights among Christians ( $\mathrm{r}$ 0.23), Muslims (r 0.40), and Hindus (r 0.33). Supporting authority, law, and order on the one side and empathy on the other, seem to be favorable for socioeconomic rights for all religious groups, particularly among Muslims.

Among the socio-political traits, multiculturalism relates moderately to socioeconomic rights for Christians (r 0.21), Muslims (r 0.17), and Hindus (r 0.21). Only among Christians left-wing political 
orientation ( $\mathrm{r}-0.20$, the scale going from left to right) is moderately related to socioeconomic rights. It means that openness to other cultures and left-wing political orientation (in the case of Christians) contribute to affirming socioeconomic rights among the young. We shall comment further on these findings related to background variables in the last section.

Research question 5: Which independent variables (personal and contextual religious attitudes, religious socialization, and experience of democracy) and background variables (personal profile, and psychosocial and socio-political traits) emerge as predictors of agreement with socioeconomic rights among Christians, Muslims, and Hindus?

The correlation analyses with reference to the independent variables and background variables have brought to light numerous associations with socioeconomic rights. The third stage of regression analysis reported in Table 6 reveals some strong predictors of socioeconomic rights.

Table 6. Regression analyses for socioeconomic rights with weights $(\beta)$ for each variable and total explained variance $\left(R^{2}\right.$ and adjusted $\left.R^{2}\right)$ for the three religious groups.

\begin{tabular}{|c|c|c|c|}
\hline & \multicolumn{3}{|c|}{ Socioeconomic Rights } \\
\hline & Christians & Muslims & Hindus \\
\hline \multicolumn{4}{|l|}{ Personal religious attitudes } \\
\hline \multicolumn{4}{|l|}{ Religious belief } \\
\hline Belief in personal God & $0.189 * *$ & 0.127 * & $0.156^{*}$ \\
\hline Belief in non-personal God & $0.292 * *$ & 0.112 & 0.109 \\
\hline \multicolumn{4}{|l|}{ Religious experience } \\
\hline Religious experiences & $0.148^{* *}$ & 0.004 & 0.064 \\
\hline Experience of divine intervention & 0.028 & $0.155^{* *}$ & -0.049 \\
\hline \multicolumn{4}{|l|}{ Religious practice } \\
\hline Influence of religion on daily life & $-0.092 *$ & 0.070 & 0.040 \\
\hline \multicolumn{4}{|l|}{ Contextual religious attitudes } \\
\hline \multicolumn{4}{|l|}{ Function of religion } \\
\hline Integral transformative function & 0.081 & $0.154^{* *}$ & $0.132 *$ \\
\hline \multicolumn{4}{|l|}{ Trust in Religion } \\
\hline Trust in out-group & $-0.122 * *$ & $-0.115^{*}$ & $-0.115 *$ \\
\hline \multicolumn{4}{|l|}{ Religious socialization } \\
\hline Best friend's belief and faith & $0.133^{* *}$ & 0.045 & 0.087 \\
\hline \multicolumn{4}{|l|}{ Experience of Democracy } \\
\hline \multicolumn{4}{|l|}{ Value of human dignity } \\
\hline Moral dignity & $0.106^{*}$ & $0.152 * *$ & 0.048 \\
\hline Intrinsic dignity & -0.007 & $0.097 *$ & -0.051 \\
\hline \multicolumn{4}{|l|}{ Personal profile } \\
\hline Age & 0.006 & $-0.131 * *$ & 0.024 \\
\hline \multicolumn{4}{|l|}{ Psychosocial traits } \\
\hline Empathy & 0.062 & 0.098 * & $0.178^{* *}$ \\
\hline \multicolumn{4}{|l|}{ Socio-political traits } \\
\hline Multiculturalism & $0.125^{* *}$ & 0.053 & $0.153 *$ \\
\hline 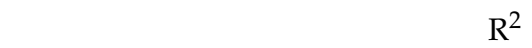 & 0.525 & 0.460 & 0.213 \\
\hline Adj. $\mathrm{R}^{2}$ & 0.507 & 0.437 & 0.178 \\
\hline
\end{tabular}

Standardized regression coefficients $(\beta)$ are significant at $p<0.00\left(^{* *}\right)$ or $p<0.05(*)$ level.

For Christians, it is noteworthy that the regression analysis of socioeconomic rights explains half of the total variance $\left(R^{2} 0.525\right.$; adjusted $\left.R^{2} 0.507\right)$. Among personal religious attitudes, belief in personal God ( $\beta$ 0.189), that in non-personal God ( $\beta$ 0.292) and religious experience $(\beta$ 0.148) emerge as rather strong predictors of agreement with socioeconomic rights. Instead, influence of religion on daily life has weak negative impact $(\beta-0.092)$. Considering the contextual religious attitudes, we find that trust in out-group $(\beta-0.122)$, namely, trusting other religions, has a moderate inverse impact. Among the features of religious socialization, best friend's belief and faith ( $\beta$ 0.133) induces agreement with socioeconomic rights. As regards the experience of democracy, the value of human 
dignity as moral dignity of persons has a moderate $(\beta$ 0.106) predictive value for Christian students. Among the background variables, the socio-political trait of openness to multiculturalism $(\beta 0.125)$ has a moderate positive impact as well. Thus, we find that in the case of Christians some religious attitudes (belief in personal God, belief in non-personal God, religious experience, and best friend's belief) induce agreement with socioeconomic rights, while influence of religion on daily life and trust in other religions reduce agreement with socioeconomic rights. With reference to experience of democracy, value of the moral dignity of persons, and openness to multiculturalism also emerge as favorable predictors of socioeconomic rights.

In the case of Muslims, the regression analysis of socioeconomic rights explains over two-fifths of the total variance $\left(R^{2} 0.460\right.$; adjusted $\left.R^{2} 0.437\right)$. Among personal religious attitudes, belief in personal God ( $\beta$ 0.127) and experience of divine intervention ( $\beta$ 0.155) emerge as favorable predictors. Among contextual religious attitudes, affirming the integral transformative function of religion $(\beta 0.154)$ emerges as a moderate predictor, whereas trust in out-group $(\beta-0.115)$ reduces agreement with socioeconomic rights. Among the variables related to democracy, we find that considering human dignity on the basis of morality $(\beta$ 0.152) is a moderate predictor and intrinsic dignity $(\beta 0.097)$ a weak one. As for the background variables, younger age $(\beta-0.131)$ and the psychosocial trait of empathy ( $\beta$ 0.098) are found to have moderately positive impact on the socioeconomic attitude. Thus, we find that for Muslims some religious attitudes (belief in personal God, experience of divine intervention, and integral transformative function), the moral and intrinsic dignity of the human person, and the personal characteristic of younger age and empathy emerge as positive predictors of socioeconomic rights; instead trust in other religions reduces agreement with socioeconomic rights.

For Hindus, the regression analysis of socioeconomic rights explains about one-fifth of the total variance $\left(R^{2} 0.213\right.$; adjusted $\left.R^{2} 0.178\right)$. Among personal religious attitudes, only belief in personal God ( $\beta$ 0.156) and among contextual religious attitude, only integral transformative function of religion ( $\beta$ 0.134) have weak predictive impact, whereas trust in out-group $(\beta-0.115)$ has a weak inverse impact on socioeconomic attitude. None of the aspects of democracy has a significant impact. As for the background variables, the psychosocial trait of empathy $(\beta$ 0.178) and the socio-political trait of multiculturalism ( $\beta$ 0.153), emerge as moderate predictors of agreement with socioeconomic rights. Thus, for Hindus some religious attitudes (belief in personal God and integral transformative function) and background characteristics (empathy and multiculturalism) emerge as positive predictors socioeconomic rights; instead, trust in other religions reduces agreement with socioeconomic rights.

Overall, we can affirm that only some aspects of independent and background variables have predictive value. Among religious variables, only belief in personal God and trust in other religions (with diminishing effect) have predictive value in the case of all the three religious groups. Among Christians and Muslims, there are more religious factors relevant to socioeconomic rights than among Hindus. As the percentage of total explained variance brings to light, the independent variables taken together contribute more to agreement with socioeconomic rights among Christians and Muslims than among Hindus. The emerging predictors related to religious attitude and socialization evince how religions support socioeconomic human rights. We shall take up these findings for further discussion in the following section.

\section{Discussion on the Salient Findings and Their Implications}

Our empirical research among the college students in Tamil Nadu has led to some interesting findings that address the questions at the basis of this study: What understanding of socioeconomic rights do the students have? To what extent are they concerned about these rights? Do the religious traditions to which they belong influence their socioeconomic attitude? Does their experience of democracy support socioeconomic rights? We shall sum up the salient findings with regard to these interrogatives and discuss their implications. 


\subsection{Implications of the Understanding and Importance of Socioeconomic Rights}

In the first place, our findings reveal that students have a comprehensive understanding of socioeconomic rights. The reliable scale that we have empirically established among Christians, Muslims, and Hindus, covers all essential features of socioeconomic rights. When compared to the other generations of human rights in the broader research project 'Religion and Human Rights,' namely, civil rights, political rights, and judicial rights, as well as right to life that have been covered separately, the set of socioeconomic rights is perceived more distinctly by the students, as evidenced in a factor analysis of the 54 items covering all generations of human rights (Anthony and Sterkens 2020). The findings of the present study also reveal that the students clearly agree with socioeconomic rights, and this may be explained by the fact that the respondents mostly belong to the lower middle class. The Christian minority group affirms it more strongly than Muslims and Hindus. Among Muslims, younger students and women are more sensitive to socioeconomic rights than older Muslims and Muslim men.

The clear perception and the affirmation of socioeconomic rights among the students is understandable, as socioeconomic status is the path to a brighter future, particularly for the respondents who mostly belong to the lower middle-class level. A national survey a decade ago (deSouza et al. 2009, pp. 103-9) brought to light the intersection between socioeconomic status, life aspirations, and education. As the socioeconomic status improves, youths' uncertainty about the future decreases; just as their educational status determines their levels of anxiety and aspirations, higher aspirations go hand in hand with the desire to secure the benefits of higher education. It is therefore crucial that the educational process-without losing its holistic concern-should contribute both to the personal aspirations of students as well as to their socioeconomic development. The professionalization of education founded on quality, innovation, and research indispensable for socioeconomic development in effect is the focus of the New Education Policy in India promoted by the Ministry of Human Resource Development. The National Education Policy 2020 approved by the Union Cabinet on 29 July 2020, in the Introduction elucidates: "The world is undergoing rapid changes in the knowledge landscape. With various dramatic scientific and technological advances, such as the rise of big data, machine learning, and artificial intelligence, many unskilled jobs worldwide may be taken over by machines, while the need for a skilled workforce, particularly involving mathematics, computer science, and data science, in conjunction with multidisciplinary abilities across the sciences, social sciences, and humanities, will be increasingly in greater demand. With climate change, increasing pollution, and depleting natural resources, there will be a sizeable shift in how we meet the world's energy, water, food, and sanitation needs, again resulting in the need for new skilled labor, particularly in biology, chemistry, physics, agriculture, climate science, and social science. The growing emergence of epidemics and pandemics will also call for collaborative research in infectious disease management and development of vaccines and the resultant social issues heightens the need for multidisciplinary learning. There will be a growing demand for humanities and art, as India moves towards becoming a developed country as well as among the three largest economies in the world."13

Educational qualification is particularly indispensable in the case of the minorities: Not having the 'social capital' (Putnam and Feldstein 2004) available for the majority community, in a highly competitive world, affirmation of socioeconomic human rights and building up the 'cultural capital' through education become the essential pathway to their socioeconomic development and wellbeing. The educational institutions spread across the subcontinent run by the Christian minority community speak volumes in this regard and explain Christian students' stronger favorableness to the socioeconomic rights. The greater sensitivity of younger Muslims and Muslim women to socioeconomic rights can be attributed to the greater human rights awareness among the younger generation and the effect of education and feminism on Muslim women. Maybe they perceive their

13 https://www.mhrd.gov.in/sites/upload_files/mhrd/files/NEP_Final_English.pdf (accessed on 17 August 2020). 
vulnerability in this regard more than other groups. Not that other youth are unconcerned about human rights issues, but it may be of greater interest to youth, especially women, conditioned by traditional culture.

\subsection{Implications of the Impact of Religion on Socioeconomic Rights}

Our findings bring to light that there are similarities and differences in the impact of specific religious attitudes on students' agreement with socioeconomic rights. In the case of personal religious attitudes, the belief system of the three religious traditions has strong associations with socioeconomic rights, with the belief in a personal God having a predictive value. Only in the case of Christians, the belief in a non-personal God has a predictive value as well. In a previous study among younger school students in Tamil Nadu, we found that besides the general belief in God, the specific beliefs about Jesus (his being inspired by the spirit, his liberation, his solidarity) and about Mohammed (his being a prophet and a mystic, his uniqueness, his active religion), had some influence on their attitudes towards socioeconomic rights. Curiously, similar beliefs about Rama did not produce significant associations, except for Rama's inspiration in the case of Hindu students (Anthony 2013). In both studies, Hindus seem to be less influenced by personal religious attitudes in their affirmation of socioeconomic rights than Christians and Muslims. This may derive from the vast pluralism and freedom possible in the belief system of Hindus. Nevertheless, in the present research we found that belief in a personal God has predictive impact also in the case of Hindu students. In effect, Hindu tradition at the popular level is centered on images of personal Gods, images preferred by believers from among the rich variety of representations of the divine.

Religious experience and experience of divine intervention have strong associations with socioeconomic rights particularly among Christians and Muslims. Whereas religious experience has a predictive value in the case of Christians, experience of divine intervention has a predictive value in the case of Muslims. In the case of Hindus, religious experience is associated with socioeconomic rights, but not resulting in a significant contribution in the regression analysis, contrary to our expectations based on the prominence of mystical experience in Hinduism. Again, only in the case of Christians and Muslims, we find religious practice-prayer and religious services-inducing attitudes towards socioeconomic rights. It means that in the case of Christian and Muslim students some aspects of personal religious experience and practice provide the meta-ethical predictive basis for socioeconomic rights. As we have seen, Christianity and Islam have a positive theological view of human work and wealth for ensuring human flourishing. Although Hindu tradition also provides an overall framework for the value of human life and labor, its experience of the transcendental reality tends to relativize the material realities as an illusion (maya) and the socioeconomic situation as karma (fate resulting from previous actions). Might these be explanations for the lack of influence of Hindus' religious experiences and religious practices on socioeconomic rights?

Among contextual religious attitudes, agreement with the integral transformative function of religion shows strong association with socioeconomic rights in all three religious groups, although it has predictive value only for Muslims and Hindus. As an emerging factor, integral transformative function implies that religions should try to influence public opinion on social problems; should publicly stand up for the underclass; should take public responsibility for societal development; should take joint responsibility with the state for the national culture; and all these without neglecting the responsibility for the spiritual growth of persons. It means that religious traditions with their higher ideals and universal visions can influence the concrete social, political, and economic realities of people. The fact that young students-mostly belonging to lower economic status-who affirm the integral transformative function of religions (with predictive value for Muslims and Hindus) are in greater agreement with socioeconomic rights suggests the significance of 'liberation theological perspective' of the religious traditions, particularly of Dalit theology (Puthanangady 1986; Prabhakar 1989; Wilfred 2007; Gorringe 2005). It also implies that religious institutions (including 
their educational institutions) are called to strengthen the transformative perspective in the religious formation of youth, and by doing so contribute to social justice, welfare, and human flourishing.

In a multi-religious context like that of India, the way one relates one's own religion to that of others has its importance. Our findings reveal that a pluralistic approach, meaning openness to other religions, is favorable to agreement with socioeconomic rights, yet exclusivism (belief in the absolute value of one's own religion) seems particularly favorable in the case of Muslims. The influence of exclusivism in the case of Muslims and to some extent in the case of the other two religious groups suggests the concern of socioeconomic solidarity that takes place predominantly within one's own community. This is confirmed by the fact that for the three religious groups, trusting in-group is positively associated with socioeconomic rights, while trusting out-group is inversely related to agreement with such rights among Christians and Muslims. In all three religious groups, trusting out-group is found to have some predictive value in reducing the agreement with socioeconomic rights. This may hint at supportive systems within the separate religious communities. With trusting in-group comes more support for socioeconomic rights, with trusting out-group the universal socioeconomic rights need less to be affirmed. The fact that the Christian minority group more strongly affirms socioeconomic human rights suggests that their trust in out-group may be rather weak. With reference to the social capital theory of Putnam and Feldstein (2004) in-group trust can be understood as 'bonding social capital' and trusting out-group as 'bridging social capital.' Probably religious institutions, particularly educational institutions, can play a vital role in inspiring young people to forge a differential pluralistic vision that recognizes the unique identity of one's own and others' faith traditions and enables reciprocal interaction based on in-group and out-group trust (Anthony et al. 2014). In such a way, both 'bonding' and 'bridging' social capital indispensable for fostering wellbeing of all, may be enhanced.

It is significant that in a multi-religious context all the aspects of religious socialization (in the family, among friends, and between religious communities) are associated with socioeconomic rights in all three religious groups, but particularly among Christians and Muslims. It means that religious socialization contributes to the 'bonding and bridging social capital' of the young hailing mostly from the lower economic section of the society. However, only in the case of Christians we find that the best friend's belief and faith induce the affirmation of socioeconomic rights. It means that peer religious socialization in the educational environment is valuable for all youth, particularly in the case of Christian youth.

\subsection{Implications of the Impact of Democratic Experience on Socioeconomic Rights}

Among a wide range of variables taken into account with regard to the experience of democracy, the one that has significant influence is the value of human dignity, particularly moral dignity having predictive value for Muslims and Christians and intrinsic dignity for Muslims. Also, in the case of Hindu students, we find significant association between moral dignity and favorableness to socioeconomic rights. Perhaps it is with regard to human dignity, particularly the intrinsic dignity of every human person and moral dignity manifested in the choices one makes, that the educational institutions can play a decisive role. With increasing socioeconomic competition based on educational qualifications and technical skills, dignity based on merit is cherished. Here lies a task for educational institutions: Without acknowledging the intrinsic dignity of every person and upholding their moral dignity, merit and competition can easily give way to ruthless and unethical socioeconomic practice.

In this vein, although the socioeconomic attitudes of the three religious groups are significantly associated with the psychological trait of empathy and the socio-political trait of openness to multiculturalism, empathy induces socioeconomic rights among Hindus and Muslims, and multiculturalism induces it among Hindus and Christians. Evidently, educational institutions can play a vital role in the cultivation of empathy by involving the students in voluntary service to the emarginated and the poor both within the campus and outside. Likewise, in a global and pluralistic world, educational institutions have the task not only of opening the minds of the young 
to multi-culturalism, but more so, to interculturality, i.e., critically enriching each other through the wealth of cultural differences (Anthony 2019; Anthony and Cimosa 2012; Anthony and Baggio 2015).

At the close of our comments on the research findings, it is pertinent to recall the optimistic vision of Adul Kalam, an Indian aerospace scientist and politician, who later served as the 11th President of India from 2002 to 2007. In India 2020. A Vision for the New Millennium, Kalam and Rajan (1998, p. xv) affirm: "After studying several vision reports of India and other countries, we still believe firmly that India can reach a developed country status by 2020. The Indian people can rise well above the present poverty and contribute more productively to their country because of their own improved health, education, and self-esteem." Far from being an established reality, the optimistic vision has suffered dire uncertainties with the COVID-19 pandemic straining the health care system and the educational processes.

With the view to reshaping the global economy, taking stock of two basic indicators of exchange value and centralization, Mair ${ }^{14}$ builds a grid of four possible scenarios in the post-pandemic world: State capitalism (centralized response prioritizing exchange value), state socialism (centralized response prioritizing the protection of life), barbarism (decentralized response prioritizing exchange value), and mutual aid (decentralized response prioritizing the protection of life). Amidst such alternatives, India, with its experience of 'mixed economy,' could move towards the last option of mutual aid, encouraging decentralized participative entrepreneurship that prioritize human life and wellbeing. As has become evident, those most affected by the pandemic are those engaged in non-formal working conditions, namely, daily laborers, migrant workers, street venders, etc., and particularly the unemployed. In a certain sense, 'social distancing' imposed by the pandemic has further widened the economic divide leaving the poor without resources for health care and survival. In the face of the current tragic experience of the vulnerable and the emarginated, our findings suggest that a democracy founded on human dignity and deeply embedded religious traditions can play their participative and transformative roles. In this vein, taking the cue from Putnam and Feldstein (2004), we conclude that besides the efforts made by government and educational institutions, initiatives of entrepreneurs, non-governmental organizations, civil societies, and youth advocacy groups, in collaboration with religious communities, can give rise to the 'bonding and bridging social capital' indispensable for fostering socioeconomic wellbeing and human flourishing in the present situation, opening up the path to a brighter future.

Author Contributions: Conceptualization, F.-V.A. and C.S.; methodology, F.-V.A. and C.S.; validation, F.-V.A. and C.S.; formal analysis, F.-V.A. and C.S.; investigation, F.-V.A. and C.S.; resources, F.-V.A. and C.S.; data curation, C.S. and F.-V.A.; writing-original draft preparation, F.-V.A.; writing-review and editing, C.S.; funding acquisition, F.-V.A. and C.S. All authors have read and agreed to the published version of the manuscript.

Funding: This research did not receive external funding, but was covered by the general budget of the authors' institutions.

Acknowledgments: The authors would like to thank Henry Rozario of the Social Work Department, Sacred Heart College, Tirupattur, Tamil Nadu, who coordinated the administration of the questionnaire and data entry. The authors also acknowledge the contribution of Hans-Georg Ziebertz, Würzburg University, coordinator of the Religion and Human Rights project, as well as the international team of experts who participated in the annual discussions on progress and results of the research project. Lastly, the authors are grateful to the peer reviewers for the dedication with which they played their role to make the article accessible to the scientific community.

Conflicts of Interest: The authors declare no conflict of interest.

14 Mair, Simon, What will the world be like after coronavirus? Four possible futures: https://theconversation.com/what-will-theworld-be-like-after-coronavirus-four-possible-futures-134085 (accessed on 20 April 2020). 


\section{References}

Anthony, Francis-Vincent. 2013. Public significance of religion with regard to socioeconomic rights in the multireligious context of Tamil Nadu, India. In Human Rights and the Impact of Religion. Edited by Johannes A. van der Ven and Hans-Georg Ziebertz. Leiden and Boston: Brill, pp. 205-44. [CrossRef]

Anthony, Francis-Vincent. 2014. Religion in a multi-religious world: An explorative empirical study of Raimon Panikkar's "Cosmotheandric vision". In Youth and Family in Today's India. Edited by Sahayadas Fernando and Jesu Pudumai Doss. Chennai: Don Bosco Publications, pp. 81-96.

Anthony, Francis-Vincent. 2019. Linee di pastorale giovanile interculturale. Rivista Lasalliana 86: 161-72.

Anthony, Francis-Vincent, and Fabio Baggio, eds. 2015. Pastorale Giovanile Interculturale. 2. Migrazione: Sfide e Buone Pratiche. Roma: LAS.

Anthony, Francis-Vincent, and Mario Cimosa, eds. 2012. Pastorale Giovanile Interculturale. 1. Prospettive Fondanti. Roma: LAS.

Anthony, Francis-Vincent, and Carl Sterkens. 2016. The impact of religion on civil human rights: An empiricaltheological study. In Catholic Approaches in Practical Theology. International and Interdisciplinary Perspectives. Edited by Claire E. Wolfteich and Annemie Dillen. Leuven: Peeters Publishers, pp. 225-52.

Anthony, Francis-Vincent, and Carl Sterkens. 2018. Extending political rights to immigrants and refugees. Empirical study among Christian, Muslim and Hindu students in the context of Indian secularism and the politics of inclusion. In Political and Judicial Rights through the Prism of Religious Belief. Edited by Carl Sterkens and Hans-Georg Ziebertz. Religion and Human Rights vol. 3. Cham: Springer, pp. 145-83. [CrossRef]

Anthony, Francis-Vincent, and Carl Sterkens. 2019a. Religion and the right to (dispose of) life: A study of the attitude of Christian, Muslim and Hindu students in India concerning death penalty, euthanasia and abortion. In Euthanasia, Abortion, Death Penalty and Religion-The Right to Life and Its Limitation. Edited by Hans-Georg Ziebertz and Francesco Zaccaria. Religion and Human Rights vol. 4. Cham: Springer, pp. $13-63$. [CrossRef]

Anthony, Francis-Vincent, and Carl Sterkens. 2019b. Religion's impact on judicial rights. An empirical study in the multi-religious context of Indian democracy. In Understanding Religion. Empirical Perspectives in Practical Theology. Edited by Ulrich Riegel, Stefan Heil, Boris Kalbheim and Alexander Unser. Essays in honour of Hans-Georg Ziebertz. Münster and New York: Waxmann, pp. 111-37.

Anthony, Francis-Vincent, and Carl Sterkens. 2020. Predictors of human rights attitude and activism in the multi-religious context of Indian democracy: Educational implications. In The Ambivalent Impact of Religion on Human Rights. Empirical Studies in Europe, Africa and Asia. Edited by Hans-Georg Ziebertz and Francesco Zaccaria. Cham: Springer, in press.

Anthony, Francis-Vincent, Chris A. M. Hermans, and Carl Sterkens. 2014. Religion and Conflict Attribution. An Empirical Study of the Religious Meaning System of Christian, Muslim and Hindu Students in Tamil Nadu, India. Leiden and Boston: Brill. [CrossRef]

Anthony, Francis-Vincent, Francesco Zaccaria, and Carl Sterkens. 2020. Impact of religion on socioeconomic rights: An empirical study of Italian students' attitude. In International Empirical Studies on Religion and Socioeconomic Human Rights. Edited by Hans-Georg Ziebertz. Religion and Human Rights vol. 5. Cham: Springer, pp. 63-100. [CrossRef]

Antoine, Robert. 1968a. Hindu ethics: 1. General ethics. In Religious Hinduism. A Presentation and Appraisal, 3rd ed. Edited by Richard V. De Smet. Allahabad: St. Paul Publications, pp. 109-16.

Antoine, Robert. 1968b. Hindu ethics: 2. Special Ethics. In Religious Hinduism. A Presentation and Appraisal, 3rd ed. Edited by Richard V. De Smet. Allahabad: St. Paul Publications, pp. 117-25.

Basu, Durga Das. 1990. The Essence of Hinduism. A Discourse on Comparative Religion on the Background of Hinduism. New Delhi: Prentice-Hall of India.

Basu, Kaushik. 2000. Whither India? The Prospect of prosperity. In India. Another Millennium? Edited by Romila Thapar. New Delhi: Penguin, pp. 193-211.

Brown, Alan. 2007. Christianity. In Ethical Issues in Six Religious Traditions, 2nd ed. Edited by Peggy Morgan and Clive A. Lawton. Edinburgh: Edinburgh University Press, pp. 216-82.

Bullock, Heather E. 1999. Attribution for poverty: A comparison of middle-class and welfare recipient attitudes. Journal of Applied Social Psychology 29: 2015-82. [CrossRef] 
Chakravarti, Ranabir. 2019. The Roman empire, Berenike, Socotra and the Indian seaboards: Maritime intercolcking (c. Late First Century BCE-300 CE). In Questioning Paradigms. Constructing Histories. A Festschrift for Romila Thapar. Edited by Kumkum Roy and Naina Dayal. New Delhi: Aleph, pp. 346-62.

Cozzarelli, Catherine, Anna V. Wilkinson, and Michael J. Tagler. 2001. Attitudes towards the poor and attributions for poverty. Journal of Social Issues 57: 207-27. [CrossRef]

Das, Gurcharan. 2007. India Unbound. From Independence to the Global Information Age. New Delhi: Penguin Books. deSouza, Peter Ronald, Sanjay Kumar, and Sandeep Shastri, eds. 2009. Indian Youth in a Transforming World. Attitudes and Perceptions. New Delhi: Sage Publications.

Fredericks, James. 2015. Survey of Catholic Social Teachings. Journal of Dialogue \& Culture 4: 108-16.

Gorringe, Hugo. 2005. Untouchable Citizens. Dalit Movements and Democratization in Tamil Nadu. Cultural Subordination and the Dalit Challenge. New Delhi: Sage Publications, vol. 4.

Gurukkal, Rajan. 2019. The nature of ports and forms of exchange on the seaboards of peninsular India during classical Graeco-Roman times. In Questioning Paradigms. Constructing Histories. A Festschrift for Romila Thapar. Edited by Kumkum Roy and Naina Dayal. New Delhi: Aleph, pp. 329-45.

Hart, David A. 2007. Trading Faith: Global Religion in an Age of Rapid Change. Alresford: O Books/John Hunt Publishing Ltd.

Hasan, Zoya. 2009. Politics of Inclusion. Castes, Minorities, and Affirmative Action. New Delhi: Oxford University Press.

Irish, Jerry. 2003. A Christian response to the Universal Declaration of Human Rights by the world's religions. In Human Rights and Responsibilities in the World Religions. Edited by Joseph Runzo, Nancy M. Martin and Arvind Sharma. Oxford: Oneworld, pp. 159-66.

Kalam, Avul Pakir Jainulabdeen Abdul, and Yagnaswami Sundara Rajan. 1998. India 2020. A Vision for the New Millennium. New Delhi: Penguin Books.

Magni, Sergio Filippo. 2011. Bioetica. Roma: Carocci.

Maliekal, John. 1977. Post- Independence Economic Policies. Bangalore: Centre for Social Action.

Menski, Werner. 2007. Hinduism. In Ethical Issues in Six Religious Traditions, 2nd ed. Edited by Peggy Morgan and Clive A. Lawton. Edinburgh: Edinburgh University Press, pp. 1-60.

Müller, Werner. 1993. Economia e religione. In Nuovo Dizionario delle Religioni. Edited by Han Waldenfels. Cinisello Balsamo: Edizione San Paolo, pp. 277-79.

Nanji, Azim. 2007. Islam. In Ethical Issues in Six Religious Traditions, 2nd ed. Edited by Peggy Morgan and Clive A. Lawton. Edinburgh: Edinburgh University Press, pp. 283-342.

Neill, Stephen. 1984. A History of Christianity in India. The Beginnings to AD 1707. Cambridge: Cambridge University Press.

O'Connell, Paul. 2011. The death of socio-economic rights. The Modern Law Review 74: 532-54. [CrossRef]

Panikkar, Raimon. 1993. The Cosmotheandric Experience. Emerging Religious Consciousness. Maryknoll: Orbis Books.

Pontifical Council for Justice and Peace. 2004. Compendium of the Social Doctrine of the Church. Vatican: Libreria Editrice Vaticana, Available online: http://www.vatican.va/ (accessed on 9 May 2020).

Prabhakar, M. E., ed. 1989. Towards a Dalit Theology. Delhi: ISPCK.

Puthanangady, Paul, ed. 1986. Towards an Indian Theology of Liberation. The statement papers and the proceedings of the Indian Theological Association (28-30 December 1985). Bangalore: ITA and NBCLC.

Putnam, Robert D., and Lewis M. Feldstein. 2004. Better Together: Restoring the American Community. New York: Simon \& Schuster.

Quinn, Philip. 2003. Christian ethics and human rights. In Human Rights and Responsibilities in the World Religions. Edited by Joseph Runzo, Nancy M. Martin and Arvind Sharma. Oxford: Oneworld, pp. 233-45.

Raychoudhary, S. C. 1989. Social, Cultural and Economic History of India. Ancient Times, 4th ed. Delhi: Surjeet Publications. Schuck, Michael J. 1994. Modern Catholic social thought. In The New Dictionary of Catholic Social Thought. Edited by Judith A. Dwyer. Collegeville: Liturgical Press, pp. 611-32.

Shaghil, M. 1999. Islamic model for socio-economic development. In Indian Muslims. Precepts E Practices. Edited by Noor Mohammad. Jaipur-New Delhi: Rawat Publications, pp. 114-22.

Singh, Ujjwal Kumar, ed. 2009. Human Rights and Peace. New Delhi: Sage.

Sontheimer, Günther D. 1993. Etica III: Induismo. In Nuovo Dizionario delle Religioni. Edited by Han Waldenfels. Cinisello Balsamo: Edizione San Paolo, pp. 326-28. 
Sterkens, Carl, Rafael Isharianto, and Paul Vermeer. 2019. Religion and inclusive society: Attitudes towards the poor among Muslim and Christian students in Surabaya. Journal of Empirical Theology 32: 36-69. [CrossRef] Thapar, Romila. 2014. The Past as Present. Forging Contemporary Identities through History. New Delhi: Aleph.

Thapar, Romila. 2019. A response to the conference. In Questioning Paradigms. Constructing Histories. A Festschrift for Romila Thapar. Edited by Kumkum Roy and Naina Dayal. New Delhi: Aleph, pp. 437-69.

van der Ven, Johannes A., Jaco S. Dreyer, and Henrik J. C. Pieterse. 2004. Is There a God of Human Rights? The Complex Relationship between Human Rights and Religion: A South African Case. Leiden/Boston: Brill.

Viswanathan, V. N., ed. 2008. Human Rights—Twenty First Century Challenges. Delhi: Kalpaz Publications.

Wilfred, Felix. 2007. Dalit Empowerment. Commemorating the Fortieth Anniversary of NBCLE in Service of the Church and the Nation. Delhi: ISPCK.

(C) 2020 by the authors. Licensee MDPI, Basel, Switzerland. This article is an open access article distributed under the terms and conditions of the Creative Commons Attribution (CC BY) license (http://creativecommons.org/licenses/by/4.0/). 